\title{
IDENTIFIKASI MACAM CEDERA PADA PASIEN KLINIK TERAPI FISIK FAKULTAS ILMU KEOLAHRAGAAN UNY
}

\author{
Oleh: Ali Satia Graha,. M. Kes \\ Dosen Jurusan Pendidikan Kesehatan dan Rekreasi FIK UNY
}

Abstrak

Penelitian ini bertujuan untuk mengetahui identifikasi macam cedera pada pasien klinik terapi fisik Fakultas Ilmu keolahragaan Universitas Negeri Yogyakarta (KTF FIK UNY).

Penelitian ini merupakan penelitian deskriptif dengan menggunakan metode survei. Subjek penelitian dalam penelitian ini adalah pasien KTF FIK UNY yang mengalami cedera anggota gerak tubuh pada tahun 2010 dan 2011. Analisis data yang digunakan dalam penelitian ini menggunakan perhitungan statistik deskriptif persentase.

Hasil penelitian menunjukkan bahwa terdapat sepuluh macam cedera anggota gerak tubuh yang dialami pasien KTF FIK UNY, yaitu cedera leher, bahu, siku, pergelangan tangan, jari tangan, pinggang, panggul, lutut, engkel, dan jari kaki. Dari sepuluh macam cedera tersebut cedera bahu merupakan cedera yang paling sering dialami pasien KTF FIK UNY dengan persentase 20,29 \% pada tahun 2010 dan 23,03 $\%$ pada tahun 2011, sedangkan cedera yang paling sedikit dialami adalah cedera jari kaki dengan persentase $0,23 \%$ pada tahun 2010 dan $0,58 \%$ pada tahun 2011 . Selain itu pada penelitian ini dapat juga diketahui bahwa pada tahun 2010 dan 2011 pasien lakilaki lebih banyak mengalami cedera dibandingkan pasien perempuan dari sepuluh macam cedera yang terjadi, kecuali pada tahun 2011 bahwa pasien perempuan lebih banyak mengalami cedera bahu dibandingkan pasien laki-laki.

\section{Kata Kunci: Cedera, Pasien KTF FIK UNY.}

Hiruk pikuk kehidupan manusia dan kesibukan akan aktivitas dengan didukung adanya kebebasan dalam mendapatkan dan mempergunakan ilmu dan teknologi, memacu manusia untuk bersaing demi kelayakan hidup di lingkungan tersebut. Di sisi lain, tingginya aktivitas dan kecanggihan teknologi membuat manusia banyak mengalami efek negatif, misalnya sakit yang diakibatkan oleh cedera akibat aktivitas sehari-hari.

Keluhan cedera akibat aktivitas sehari-hari banyak dialami oleh semua orang seperti yang terjadi di Indonesia. Hardianto Wibowo (1994: 16), merinci lokasi cedera pada olahragawan dengan persentase sebagai berikut: (1) Kepala $1 \%$, (2) Leher 1,5 \%, (3) Lengan $14 \%$, (4) Punggung $16 \%$, (5) Tangan dan pergelangan tangan $4 \%$, (6) Pingang/panggul 5,5 \%, (7) Paha $9 \%$, (8) Lutut 22,5 \%, (9) Kaki/tungkai bawah $10 \%$, (10) Tumit $14 \%$, (11) Telapak kaki 1,5\%. Cedera yang terjadi pada seseorang memacu orang tersebut untuk mencari pengobatan yang dapat menyembuhkan dengan cepat, baik jalur medis maupun tradisional. Salah satu jenis pengobatan adalah terapi masase untuk membantu mengurangi keluhan cedera ringan akibat aktivitas sehari-hari. Penanganan cedera dapat dilakukan di 


\section{MEDIKORA Vol. IX, No 1 Oktober 2012}

pusat-pusat pelayanan terapi fisik dan terapi masase. Salah satu yang berkembang di Yogyakarta yaitu klinik terapi fisik yang beralamat jalan Colombo nomor 01, di bawah naungan Universitas Negeri Yogyakarta di Fakultas Ilmu Keolahraga sebagai pusat pelayanan pengabdian kepada masyarakat untuk menunjang Tri Darma Perguruan Tinggi.

KTF FIK UNY memberikan pelayanan mulai dari pukul 10.00 WIB sampai dengan 20.00 WIB, bagi pasien yang mengalami kelelahan tubuh akibat aktivitas fisik yang berlebih dan pasien yang mengalami cedera baik akibat aktivitas olahraga maupun aktivitas seharihari. Penanganan yang diberikan pada pasien yaitu menggunakan terapi masase (pijat) tanpa menggunakan obat-obatan, sehingga pasien merasa aman dan terhindar dari pengaruh kimiawi obat.

Rasa aman dan nyaman yang didapatkan oleh pasien meningkatkan jumlah kunjungan ke KTF FIK UNY. Hasil observasi awal keluhan pasien di KTF FIK UNY antara lain sebagai berikut: (1) Pasien KTF FIK UNY mengalami keluhan cedera pada anggota tubuh akibat aktivitas sehari-hari di tempat kerja, (2) Pasien KTF FIK UNY mengalami keluhan cedera pada anggota tubuh akibat aktivitas olahraga, (3) Pasien KTF FIK UNY mengalami keluhan kelelahan akibat aktivitas kerja sehari-hari, (4) Pasien KTF FIK UNY mengalami keluhan kelelahan akibat aktivitas olahraga, (5) Pasien KTF FIK UNY mengalami keluhan gangguan sakit pada tubuh. Berdasarkan observasi awal tersebut, dirasa perlu adanya pengidentifikasian macam-macam cedera yang terjadi pada pasien yang berkunjung di KTF FIK UNY. Oleh karena itu, peneliti ingin meneliti lebih dalam lagi tentang "Identifikasi macam cedera pada pasien klinik terapi fisik Fakultas Ilmu keolahragaan Universitas Negeri Yogyakarta”.

\section{KAJIAN PUSTAKA}

Cedera merupakan hal yang sulit dihindari oleh masyarakat saat melakukan aktivitas sehari-hari, seperti bekerja maupun berolahraga. Cedera merupakan rusaknya jaringan lunak atau keras disebabkan adanya kesalahan teknis, benturan atau aktivitas fisik yang melebihi batas beban latihan yang dapat menimbulkan rasa sakit sehingga otot dan tulang tidak lagi dalam keadaan anatomis (Cava, 1995: 145) yang dikutip (Antony Eko Raharjo, 2008: 32). Sementara oleh Ali Satia Graha dan Bambang Priyonoadi (2009: 43) menyatakan bahwa terdapat dua macam cedera yang dapat timbul akibat melakukan aktivitas sehari-hari maupun berolahraga yaitu cedera ringan dan cedera berat. Kedua macam cedera tersebut dapat dijabarkan sebagai berikut: 


\section{MEDIKORA Vol. IX, No 1 Oktober 2012}

1. Cedera ringan yaitu cedera yang terjadi karena tidak ada kerusakan yang berarti pada jaringan tubuh, misalnya kekakuan otot dan kelelahan. Cedera ringan tidak memerlukan penanganan khusus, biasanya dapat sembuh sendiri setelah istirahat.

2. Cedera berat yaitu cedera serius pada jaringan tubuh dan memerlukan penanganan khusus dari medis, misalnya robeknya otot, tendon, ligamen atau patah tulang.

Menurut Bambang Priyonoadi (2006: 8), Sadoso (1993: 268), dan Giam dan Teh (1992: 92), ada dua jenis cedera pada otot atau tendo dan ligamentum, yaitu:

a) Sprain

Sprain adalah cedera pada ligamentum. Cedera ini yang paling sering terjadi pada berbagai cabang olahraga. Sprain adalah cedera pada sendi, yang ditandai dengan terjadinya robekan pada ligamentum. Hal ini terjadi karena stres berlebihan yang mendadak atau penggunaan berlebihan yang berulang-ulang dari sendi. Sprain biasanya berkaitan dengan strain dari tendon-tendon yang menyilang di sendi siku, misalnya biceps brachii, triceps brachii. Penyebab tersering ialah cedera karena hiperekstensi, misalnya pada tangan yang terulur dengan lengan siku dalam keadaan ekstensi penuh, atau bila berulang-ulang melempar, misalnya bola atau lembing. Timbul nyeri bila siku diekstensikan atau difleksikan secara penuh.

Berdasarkan berat ringannya cedera Bambang Priyonoadi (2006: 8), Giam dan Teh (1992: 195), membagi sprain menjadi tiga tingkatan, yaitu:

(1) Sprain Tingkat I

Pada cedera ini terdapat sedikit hematoma dalam ligamentum dan hanya beberapa serabut yang putus. Cedera menimbulkan rasa nyeri tekan, pembengkakan dan rasa sakit pada daerah tersebut.

(2) Sprain Tingkat II

Pada cedera ini lebih banyak serabut dari ligamentum yang putus, tetapi lebih separuh serabut ligamentum yang utuh. Cedera menimbulkan rasa sakit, nyeri tekan, pembengkakan, efusi (cairan yang keluar) dan biasanya tidak dapat menggerakkan persendian tersebut.

(3) Sprain Tingkat III

Pada cedera ini seluruh ligamentum putus, sehingga kedua ujungnya terpisah. Persendian yang bersangkutan merasa sangat sakit, terdapat darah dalam persendian, pembekakan, tidak dapat bergerak seperti biasa, dan terdapat gerakan-gerakan yang abnormal.

b) Strain 


\section{MEDIKORA Vol. IX, No 1 Oktober 2012}

Menurut C.K Giam dan K.C Teh (1992: 93) strain adalah kerusakan pada suatu bagian otot atau tendo karena penggunaan yang berlebihan ataupun stres yang berlebihan. Menurut Hartono Satmoko (1992: 193), strain otot adalah kerusakan pada bagian otot atau tendon (termasuk titik-titik pertemuan antara otot dan tendon) karena penggunaan yang berlebihan ataupun stres yang berlebihan. Terjadinya robekan jaringan bisa bersifat makroskopis (dapat dilihat dengan mata telanjang) atau mikroskopis (hanya terlihat dengan mikroskop). Tendinitis achilles adalah suatu peradangan pada tendon achilles, yaitu urat daging yang membentang dari otot betis ke tumit. Otot betis dan tendon achilles berfungsi menurunkan kaki bagian depan setelah tumit menyentuh tanah dan mengangkat tumit ketika jari-jari kaki ditekan sebelum melangkah dengan kaki yang lainnya.

Berdasarkan berat ringannya cedera Sadoso Sumosardjuno (1995: 15), membedakan strain menjadi 3 tingkatan, yaitu:

(1) Strain Tingkat I

Pada strain tingkat I, terjadi regangan yang hebat, tetapi belum sampai terjadi robekan pada jaringan muscula tendineus.

(2) Strain Tingkat II

Pada strain tingkat II, terdapat robekan pada unit musculo tendineus. Tahap ini menimbulkan rasa nyeri dan sakit sehingga kekuatan berkurang.

(3) Strain Tingkat III

Pada strain tingkat III, terjadi robekan total pada unit musculo tendineus. Biasanya hal ini membutuhkan tindakan pembedahan.

Jika melihat dari macam cedera di atas, maka cedera yang terjadi akan menimbulkan berbagai macam keluhan, seperti nyeri, panas, serta penurunan fungsi gerak dari anggota tubuh yang mengalami cedera tersebut. Hal semacam itu di dunia medis lebih dikenal dengan istilah inflamasi atau peradangan yang memiliki ciri-ciri panas, merah, bengkak, nyeri dan penurunan fungsi. Seperti yang diungkapkan oleh Ali Satia Graha dan Bambang Priyonoadi (2009: 46), tanda-tanda peradangan pada cedera jaringan tubuh yaitu:

1. Kalor atau panas karena meningkatnya aliran darah ke daerah yang mengalami cedera.

2. Tumor atau bengkak disebabkan adanya penumpukan cairan pada daerah sekitar jaringan yang cedera.

3. Rubor atau merah pada bagian cedera karena adanya pendarahan. 


\section{MEDIKORA Vol. IX, No 1 Oktober 2012}

4. Dolor atau rasa nyeri, karena terjadi penekanan pada saraf akibat penekanan baik otot maupun tulang.

5. Functiolaesa atau tidak bisa digunakan lagi, karena kerusakannya sudah cedera berat.

Dari berbagai macam tanda peradangan tersebut di atas, dapat diketahui bahwa selain menimbulkan berbagai macam keluhan, peradangan juga merupakan mekanisme mobilisasi pertahanan tubuh dan reaksi fisiologis dari jaringan rusak baik akibat tekanan mekanis, kimiawi, panas, dingin dan invasi bakteri (Wara Kushartanti, 2007: 3).

Selain mengetahui macam dan gejala apa yang terjadi pada cedera, masyarakat juga diharapkan dapat mengetahui faktor yang dapat menimbulkan cedera saat melakukan aktivitas sehari-hari. Susan J. Gorrison (2001: 320) menyatakan bahwa faktor penyebab terjadinya cedera adalah faktor ekstrinsik dan faktor instrinsik. Faktor ekstrinsik adalah faktor yang unsur-unsurnya berasal dari luar diri masyarakat tersebut, berupa perlengkapan yang salah dan faktor cuaca, sedangkan faktor instrinsik adalah faktor yang unsur-unsurnya sudah ada dalam diri masyarakat tersebut. Hal ini meliputi kelemahan jaringan, infleksibilitas atau kelebihan beban, kesalahan biomekanik dan kurangnya pengkondisian tubuh yang baik, seperti halnya cedera yang sering dialami oleh pasien KTF FIK UNY.

KTF FIK UNY awalnya merupakan bagian Laboratorium Terapi Fisik FIK UNY dari Klinik Kebugaran FIK UNY yang melayani konsultasi kesehatan, latihan kebugaran (Fitness), senam aerobik, masase olahraga dan terapi masase. Masase di klinik kebugaran sudah dikembangkan sebelum klinik terapi fisik ada. Laboratorium terapi fisik FIK UNY kemudian terpisah manajemen dari klinik kebugaran dan pada bulan oktober 2010 berubah menjadi klinik terapi fisik sebagai pengembangan usaha pelayanan terhadap masyarakat dan pengembangan penguasaan keahlian dalam bidang akademik khususnya masase dan terapi fisik di bawah Fakultas Ilmu Keolahragaan yang dinaungi oleh Universitas Negeri Yogyakarta.

Wacana dan pengetahuan yang didapat dari perkuliahan dan laboratorium terapi fisik tentang masase dan terapi sudah dikembangkan dan telah banyak mengadakan seminar, pelatihan, dan sebagai tempat studi banding dari berbagai perguruan tinggi yang memiliki Fakultas Ilmu Keolahragaan. Hasil yang telah dikembangkan oleh KTF FIK UNY, berpotensi untuk mengembangkan fisioterapi, masase dan terapi masase untuk menangani pasien yang mengalami kelelahan, cedera, maupun rehabilitasi pasca sakit dan sehabis operasi. 


\section{MEDIKORA Vol. IX, No 1 Oktober 2012}

Pasien yang mengalami berbagai macam keluhan dan cedera, biasanya datang ke klinik untuk melakukan terapi dan masase karena selain jenuh dengan obat-obatan, pasien juga menghindari dampak negatif bagi organ dalam tubuh akibat mengkonsumsi obat yang mengandung bahan kimia sehingga pasien memilih alternatif dengan penanganan pemulihan cedera dengan cara herbal. Pasien yang datang di KTF FIK UNY terdiri dari berbagai macam pasien, baik dilihat dari keluhan cedera yang dialami, usia, jenis kelamin maupun profesi yang ditekuni baik sebagai pelajar, mahasiswa, karyawan maupun atlet.

\section{METODE PENELITIAN}

Penelitian ini merupakan penelitian deskriptif dengan menggunakan metode survei. Penelitian deskriptif yaitu merupakan penelitian yang bertujuan untuk mengumpulkan informasi mengenai status suatu gejala sesuai dengan keadaan menurut apa adanya pada saat penelitian dilakukan (Suharsimi Arikunto, 1998: 309). Penelitian ini dilakukan di KTF FIK UNY selama 6-8 bulan dengan populasi penelitian pasien KTF FIK UNY. Teknik pengambilan sampel dengan cara purposive sampling.

Data yang dikumpulkan dalam penelitian ini adalah data yang diperoleh dengan melakukan survei dari populasi pasien KTF FIK UNY. Cara pelaksanaan pengumpulan data ini yaitu mengumpulkan data pasien dari tahun 2010 sampai dengan 2011 dan memisahkan data tersebut sesuai dengan jenis dan macam cedera yang terjadi pada pasien KTF FIK UNY, seperti yang diungkapkan oleh Suharsimi Arikunto (1998: 151) bahwa teknik pengumpulan data dapat menggunakan metode dokumentasi yaitu dokumen yang ada dipelajari untuk memperoleh data dan informasi dalam penelitian ini. Dokumen tersebut meliputi laporan, artikel, majalah, koran atau jurnal yang berkaitan dengan topik penelitian. Dokumen tersebut digunakan untuk mendapatkan data sekunder, seperti pada penelitian ini menggunakan dokumen laporan data pasien yang ada di KTF FIK UNY.

Data yang diperoleh kemudian dianalisis dengan menggunakan analisis data perhitungan statistik deskriptif persentase, yaitu dengan cara mengadakan persentase dan penyebaran serta memberikan penafsiran yang diperoleh atas dasar persentase tersebut. Teknik analisis ini dapat dihitung dengan menggunakan rumus sebagai berikut (Anas Sudijono, 2006: 43):

$$
\mathbf{P}=\frac{\mathbf{F}}{\mathrm{N}} \times 100 \%
$$

Keterangan: 

P: Persentase yang dicari
F: Frekuensi
$\mathrm{N}$ : Jumlah responden

\section{HASIL PENELITIAN DAN PEMBAHASAN}

Data yang diperoleh dalam penelitian ini adalah data macam-macam cedera yang terjadi pada pasien yang melakukan terapi masase di KTF FIK UNY pada bulan Januari hingga Desember tahun 2010 dan 2011. Data ini meliputi data cedera pada anggota gerak tubuh baik pada bagian atas maupun bawah. Dari data yang diperoleh dalam penelitian ini terdapat 10 macam cedera pada sendi atau anggota gerak tubuh selama 2 tahun yaitu 2010 dan 2011.

Hasil analisis menunjukkan bahwa data cedera yang dialami pasien KTF FIK UNY pada tahun 2010 dan 2011 yaitu cedera pada sendi leher, bahu, siku, pergelangan tangan, jari tangan, pinggang, panggul, lutut, engkel, dan jari kaki. Data cedera yang paling sering dialami pasien KTF FIK UNY di antara 10 cedera tersebut setiap bulan berbeda dan ada yang tidak mengalami cedera tertentu pada setiap bulannya, seperti cedera pada jari kaki.

Jika melihat dari hasil analisis data yang ada bahwa dalam 1 tahun jenis cedera yang paling sering dialami pasien yaitu cedera bahu baik pada tahun 2010 dan 2011, sedangkan cedera yang paling sedikit dialami yaitu cedera pada jari kaki baik tahun 2010 dan 2011 . Hasil data persentase cedera yang dialami pasien KTF FIK UNY selama 1 tahun pada tahun 2010 dapat dilihat lebih jelas pada diagram batang di bawah ini:

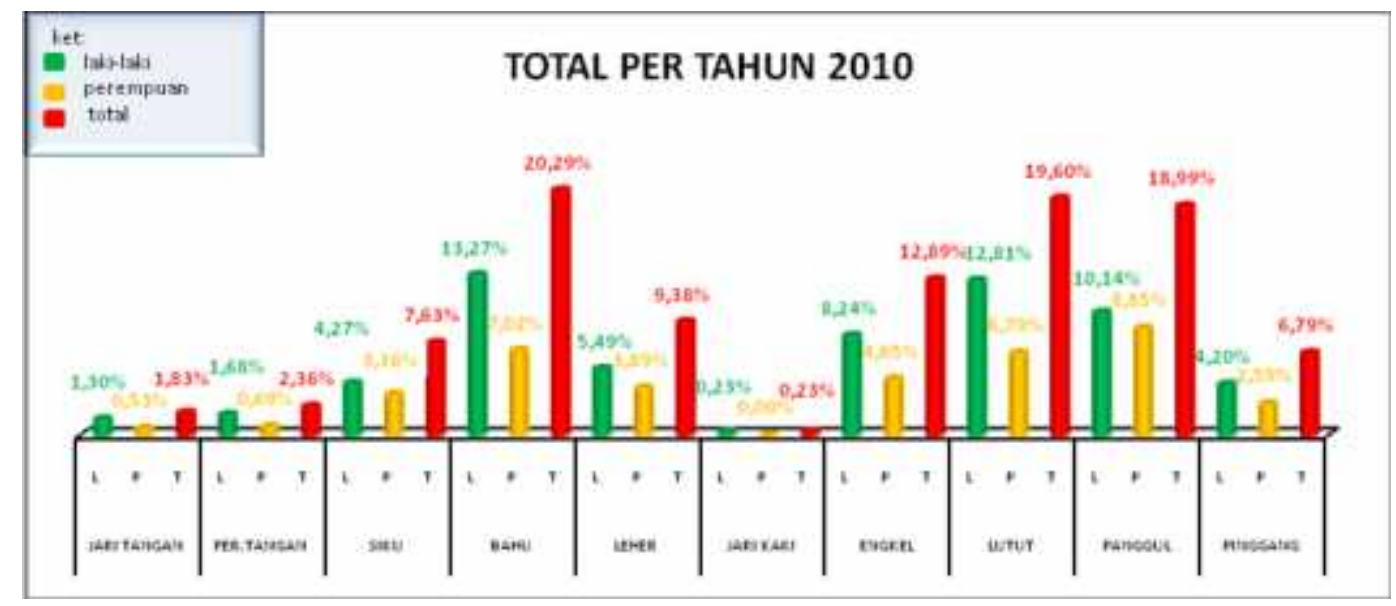

Gambar 1. Diagram Batang Cedera pada Tahun 2010

Dari gambar di atas dapat diketahui bahwa pada tahun 2010 cedera yang paling sering terjadi dari jumlah pasien keseluruhan 1311 orang yaitu cedera bahu sebanyak 266 orang dengan persentase 20,29\%. Kemudian cedera lutut sebanyak 257 orang dengan persentase $19,60 \%$. Cedera panggul sebanyak 249 orang dengan persentase 18,99\%, cedera engkel 


\section{MEDIKORA Vol. IX, No 1 Oktober 2012}

sebanyak 169 orang dengan persentase $12,89 \%$, cedera leher sebanyak 123 orang dengan presentase $9,38 \%$, cedera siku sebanyak 100 orang dengan presentase $7,63 \%$, dan cedera pinggang sebanyak 89 orang dengan persentase $6,79 \%$. Setelah itu cedera pergelangan tangan sebanyak 31 orang dengan persentase 2,36\%, kemudian cedera jari tangan sebanyak 24 orang dengan persentase $1,83 \%$ dan persentase paling sedikit yaitu cedera jari kaki 0,23 $\%$ sebanyak 3 orang.

Selain dari identifikasi macam cedera yang dialami di atas, maka dapat juga data cedera yang diperoleh diidentifikasi berdasarkan persentase cedera menurut jenis kelamin. Dari hasil data di atas diketahui bahwa cedera bahu yang paling sering dialami pasien sejumlah 266 orang terdiri dari laki-laki sebanyak 174 orang dan pasien perempuan sebanyak 92 orang. Data cedera lutut dengan jumlah 257 orang diketahui bahwa lebih banyak dialami pasien laki-laki sebanyak 168 orang sedangkan pada pasien perempuan sebanyak 89 orang. Cedera panggul yang dialami pasien dengan jumlah total 249 orang lebih banyak dialami pasien laki-laki dengan jumlah 133 orang sedangkan pasien perempuan berjumlah 116 orang. Kemudian cedera engkel dengan jumlah total pasien 169 orang terdiri dari pasien laki-laki sebanyak 108 orang dan pasien perempuan sebanyak 61 orang. Data cedera leher yang dialami pasien sebanyak 123 orang terdiri dari 72 laki-laki dan 51 perempuan, kemudian cedera siku dengan jumlah total pasien 100 orang terdiri dari pasien laki-laki 56 orang dan pasien perempuan 44 orang. Cedera pinggang yang dialami oleh pasien dengan jumlah total 89 orang terdiri dari 55 laki-laki dan 34 perempuan, sedangkan cedera pergelangan tangan yang dialami pasien sebanyak 31 orang terdiri dari 22 laki-laki dan 9 perempuan. Data cedera jari tangan yang dialami pasien dengan jumlah total 24 orang terdiri dari 17 laki-laki dan 7 perempuan, sedangkan cedera yang paling sedikit dialami oleh pasien pada tahun 2010 yaitu cedera jari kaki dengan total pasien 3 orang terdiri dari 3 pasien laki-laki.

Dari hasil data persentase jumlah cedera berdasarkan jenis kelamin di atas, maka diketahui bahwa pada tahun 2010 setiap macam cedera yang dialami pasien KTF FIK UNY lebih banyak dialami oleh pasien laki-laki dibandingkan pasien perempuan.

Selain data tahun 2010 di atas, hasil data persentase cedera yang dialami pasien KTF FIK UNY selama 1 tahun pada tahun 2011 juga dapat dilihat lebih jelas pada diagram batang di bawah ini: 


\section{MEDIKORA Vol. IX, No 1 Oktober 2012}

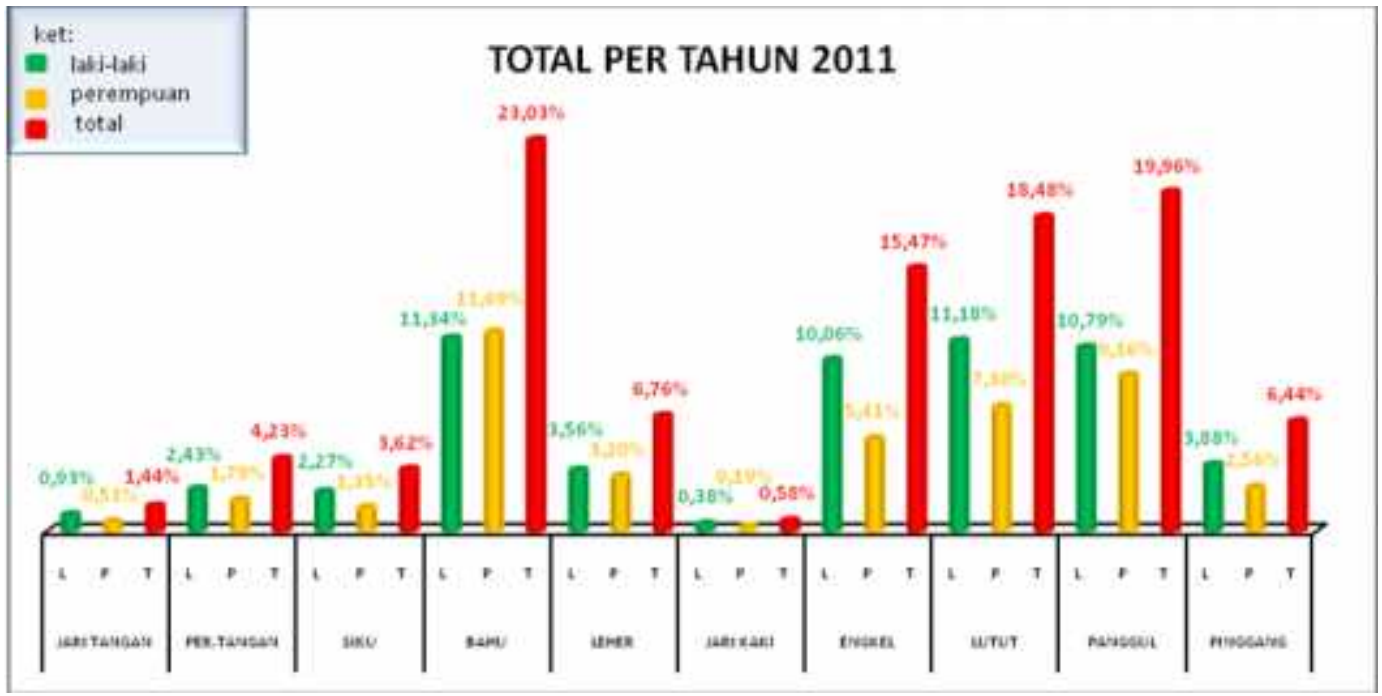

Gambar 2. Diagram Batang Cedera pada Tahun 2011

Dari gambar di atas dapat diketahui bahwa pada tahun 2011 cedera yang paling sering terjadi dari jumlah pasien keseluruhan 3122 orang yaitu cedera bahu sebanyak 719 orang dengan persentase 23,03 \%. Kemudian cedera panggul sebanyak 623 orang dengan persentase 19,96\%. Cedera lutut sebanyak 577 orang dengan persentase 18,48\%, cedera engkel sebanyak 483 orang dengan persentase 15,47\%, cedera leher sebanyak 211 orang dengan presentase $6,76 \%$, cedera pinggang sebanyak 201 orang dengan presentase $6,44 \%$, dan cedera pergelangan tangan sebanyak 132 orang dengan persentase 4,23\%. Setelah itu cedera siku sebanyak 113 orang dengan persentase 3,62 \%, kemudian cedera jari tangan sebanyak 45 orang dengan persentase $1,44 \%$ dan persentase paling sedikit yaitu cedera jari kaki $0,58 \%$ sebanyak 18 orang.

Selain dari identifikasi macam cedera yang dialami di atas, data cedera yang diperoleh diidentifikasi berdasarkan persentase cedera menurut jenis kelamin. Dari hasil data di atas diketahui bahwa cedera bahu yang paling sering dialami pasien sejumlah 719 orang terdiri dari laki-laki sebanyak 354 orang dan pasien perempuan sebanyak 365 orang. Data cedera panggul dengan jumlah 623 orang diketahui bahwa lebih banyak dialami pasien laki-laki sebanyak 337 orang sedangkan pada pasien perempuan sebanyak 286 orang. Cedera lutut yang dialami pasien dengan jumlah total 577 orang lebih banyak dialami pasien laki-laki dengan jumlah 349 orang sedangkan pasien perempuan berjumlah 228 orang. Kemudian cedera engkel dengan jumlah total pasien 483 orang terdiri dari pasien laki-laki sebanyak 314 orang dan pasien perempuan sebanyak 169 orang. Data cedera leher yang dialami pasien sebanyak 211 orang terdiri dari 111 laki-laki dan 100 perempuan, kemudian cedera pinggang dengan jumlah total pasien 201 orang terdiri dari pasien laki-laki 121 orang dan pasien perempuan 80 orang. Cedera pergelangan tangan yang dialami oleh pasien dengan jumlah 


\section{MEDIKORA Vol. IX, No 1 Oktober 2012}

total 132 orang terdiri dari 76 laki-laki dan 56 perempuan, sedangkan cedera siku yang dialami pasien sebanyak 113 orang terdiri dari 71 laki-laki dan 42 perempuan. Data cedera jari tangan yang dialami pasien dengan jumlah total 45 orang terdiri dari 29 laki-laki dan 16 perempuan, sedangkan cedera yang paling sedikit dialami oleh pasien pada tahun 2011 yaitu cedera jari kaki dengan total pasien 18 orang terdiri dari 12 pasien laki-laki dan 6 pasien perempuan.

Dari hasil data persentase jumlah cedera berdasarkan jenis kelamin di atas, maka diketahui bahwa pada tahun 2011 setiap macam cedera yang dialami pasien KTF FIK UNY lebih banyak dialami oleh pasien laki-laki dibandingkan pasien perempuan, kecuali pada cedera bahu lebih banyak dialami oleh pasien perempuan dibandingkan pasien laki-laki.

Cedera bahu merupakan cedera anggota gerak tubuh yang paling banyak dialami oleh pasien KTF FIK UNY pada tahun 2010 dan 2011 yang diakibatkan karena aktivitas kerja sehari-hari maupun aktivitas olahraga, sedangkan cedera yang paling sedikit dialami yaitu cedera jari kaki. Selain itu cedera anggota gerak tubuh pada tahun 2010 dan 2011 lebih banyak dialami oleh pasien laki-laki dibandingkan pasien perempuan pada setiap macam cedera, kecuali pada cedera bahu tahun 2011 lebih banyak dialami oleh perempuan.

\section{KESIMPULAN}

Berdasarkan hasil analisis data dan pembahasan di atas, maka kesimpulan dalam penelitian ini adalah macam cedera anggota gerak tubuh yang dialami oleh pasien KTF FIK UNY adalah cedera leher, cedera bahu, cedera siku, cedera pergelangan tangan, cedera jari tangan, cedera pinggang, cedera panggul, cedera lutut, cedera engkel, dan cedera jari kaki. Macam cedera tersebut adalah cedera yang dialami pasien KTF FIK UNY pada tahun 2010 dan 2011 dikarenakan aktivitas sehari-hari, seperti mengangkat beban, posisi tidur yang salah, keseleo saat berjalan maupun berlari, bekerja di depan komputer terlalu lama, maupun berolahraga.

Dari identifikasi macam cedera yang dialami pasien KTF FIK UNY di atas, maka dapat diketahui bahwa cedera yang paling banyak dialami yaitu cedera bahu dengan persentase 20,29\% pada tahun 2010 dan 23,03 \% pada tahun 2011, sedangkan cedera yang paling sedikit dialami adalah cedera jari kaki dengan persentase $0,23 \%$ pada tahun 2010 dan $0,58 \%$ pada tahun 2011. Selain itu dapat diperoleh juga bahwa cedera anggota gerak tubuh lebih banyak dialami oleh pasien laki-laki dibandingkan perempuan, kecuali pada cedera bahu pada tahun 2011 di mana lebih banyak pasien perempuan yang mengalami cedera dibandingkan laki-laki. 


\section{DAFTAR PUSTAKA}

Ali Satia Graha. (2009). Pedoman dan Modul Terapi Masase Frirage Penatalaksanaan Terapi Masase dan Cedera Olahraga pada Lutut dan Engkel. Yogyakarta: Klinik Terapi Fisik UNY.

Ali Satia Graha dan Bambang Priyonoadi. (2009). Terapi Masase Frirage Penatalaksanaan cedera pada anggota tubuh bagian atas. Yogyakarta: FIK UNY.

Anas Sudijono. (2006). Pengantar Statistik. Jakarta: PT Raja Grafindo Persada.

Antony Eko Raharjo. (2008). Usaha Pencegahan Cedera Pehoki Daerah Istimewa Yogyakarta. Skripsi. Yogyakarta: FIK UNY.

Bambang Priyonoadi, (2006). Pencegahan dan Perawatan Cedera. Makalah dalam Proses Pembelajaran Kuliah PPC untuk Mahasiswa FIK. Yogyakarta: FIK UNY.

C.K.Giam and K.C.Teh. (1992). Ilmu Kedokteran Olahraga (Hartono Satmoko, Terjemah) Jakarta: Penerbit: FIK UNY.

Hardianto Wibowo. (1994). Pencegahan dan Penatalaksanaan Cedera Olahraga. EGC Jakarta: Buku Kedokteran.

Hartono Satmoko. (1992). Ilmu Kedokteran Olahraga. Jakarta: Binarupa Aksara.

Sadoso Sumosardjuno. (1995). Cedera Olahraga Di Arena. Jakarta: Pusat Ilmu Keolahragaan. Koni Pusat.

Sugiyono. (2009). Metode Penelitian Administrasi. Bandung: Alfabeta.

Suharsimi Arikunto. (1998). Prosedur Penelitian Suatu Pendekatan Praktek. Jakarta: Rineka Cipta.

Susan J. Garrison. (2001). Dasar-Dasar Terapi dan Rehabilitasi Fisik. Jakarta: Hipokrates.

Wara Kushartanti. (2007). Patofisiologi Cedera Olahraga. Makalah. Yogyakarta: Klinik Terapi Fisik FIK UNY. 